\title{
Directors' Remuneration and Performance: Evidence from the Textile Sector of Bangladesh
}

\author{
Sharmin AKTER ${ }^{1}$, Md. Hossain ALI ${ }^{2}$, Md. Thasinul ABEDIN ${ }^{3}$, Balal HOSSAIN ${ }^{4}$ \\ Received: March 10, 2020 Revised: March 28, 2020 Accepted: May 07, 2020
}

\begin{abstract}
This study investigates the impact of board incentives as proxied by directors` remuneration on the financial performance of listed textile companies in Bangladesh. Using Generalized Method of Moments (GMM) and data pertaining to listed textile companies of Dhaka Stock Exchange (DSE) during the period from 2011 to 2017 (resulting in a total of 140 firm-year observations), we have estimated the firm performance equation involving directors' remuneration and board independence as the independent variables and some other control variables like firm age, size, leverage, and operating efficiency. The results reveal that there is a negative association between board remuneration and firm performance. In addition, this study finds no significant relationship between board independence and firm performance of the sample firms. Our findings suggest that higher pay to the board does not stimulate higher firm performance and, in turn, results in shareholders getting nothing in return from this and, hence, is a matter of great concern for them. Moreover, our results indirectly indicate that currently directors` remuneration in Bangladesh is not aligned with the firm performance, which has been emphasized in extant corporate governance literature. Besides, this paper further raises questions about the effectiveness of independent directors in the boards of textile firms in Bangladesh.
\end{abstract}

Keywords : Directors` Remuneration, Firm Performance, Corporate Governance, Generalized Method of Moments (GMM), Bangladesh

JEL Classification Code: G34, M41, C58

\section{Introduction}

The remuneration arrangements of publicly-traded companies have become a center of investigation due to big corporate failures, changes in executive

${ }^{1}$ First and Corresponding Author. Lecturer, Department of Accounting \& Information Systems, Faculty of Business Studies, Jashore University of Science \& Technology, Bangladesh [Postal Address: Dept. of Accounting \& Information Systems, Jashore University of Science \& Technology, Jashore - 7408, Bangladesh] Email:sharmin_ais@just.edu.bd

${ }^{2}$ Lecturer, Department of Accounting \& Information Systems, Faculty of Business Studies, Jashore University of Science \& Technology, Bangladesh. Email: hossain.ais@just.edu.bd

${ }^{3}$ Assistant Professor, Department of Accounting, University of Chittagong, Bangladesh. Email: abedin@cu.ac.bd

${ }^{4}$ Graduate Student, MBA (Finance \& Business Analytics), Texas

Christian University, Texas, USA. Email:balal.hossain@tcu.edu

(c) Copyright: The Author(s)

This is an Open Access article distributed under the terms of the Creative Commons Attribution Non-Commercial License (http://Creativecommons.org/licenses/by-nc/4.0/) which permits unrestricted noncommercial use, distribution, and reproduction in any medium, provided the original work is properly cited. remuneration structure and major responsibilities played by these executives (Müller, 2014). The Board of Directors (commonly regarded as 'the board') is the dominant and primary instrument of modern corporate governance entrusted with the responsibility of aligning interests of shareholders with management (Brennan , 2006; Rose, 2005). The directors remuneration is, in a sense, the cost of this corporate governance mechanism. In another sense, it is the shareholders' systemic investment in corporate governance. This cost is born or the investment is undergone by the shareholders, to protect their own rights and increase the value of their investment in the firm. Although it is logical to expect that the expertise and skills of the board should have a positive effect on the financial performance and profitability of firms, little is known about the effect of their remuneration packages on the firms` overall financial performance (Müller, 2014) especially in the context of emerging economies like Bangladesh. The relationship between such remuneration and the financial performance of the firm, which this study intends to investigate in the context of Bangladeshi listed textile companies, will serve two important purposes. 
First, it will delineate the extent to which such cost is justified given the return in the form of its impact on the firm's financial performance (Hassan, Christopher, \& Evans, 2003; Gregg, Machin, \& Szymanski, 1993). The financial performance is an extremely important indicator of board effectiveness and proper justification for the board's remuneration (Gregg et al., 1993). It helps the firms maintain a going concern and is an important yardstick of shareholder value and the firm's ability to distribute dividends (Müller, 2014).

Second, the findings will deal with an important and debated public policy issue. The result will shed light on and provide indirect evidence about the way the board's remuneration is set. Directors' pay will certainly impact positively on firm performance if the payment mechanism effectively elicits/incentivizes the board to do so. Thus, a positive impact of pay on performance will indirectly reflect whether directors are paid for performance.

Contrarily, the board will fall short of incentives to improve firm performance if they receive benefits based on bases that are unrelated to firm performance. For example, if board remuneration is determined more by firm size instead of performance, directors will be more inclined to pursue mergers and acquisitions irrespective of the benefit to companies, stakeholders and the economy as a whole (Gregg et al., 1993). So, this is clearly a matter of concern for different stakeholders of firms.

Our study covers 20 textile firms listed in the DSE of Bangladesh during the years 2011 to 2017 resulting in 140 firm years. Generalized Method of Moments (GMM) has been used to estimate our firm performance equation where board remuneration and board independence are the independent variables along with other control variables. We have controlled for firm age, size, leverage, and operating efficiency. Our results indicate that firm performance is negatively associated with board pay. Moreover, board independence has no significant association with firm performance. The results indicate that board pay fails to motivate to incentivize the boards and to stimulate higher firm performance. This suggests that the pay mechanism of boards of companies should be reappraised and reformed in a manner that can positively impact firm performance and returns to shareholders. Besides, the role of independent directors should be reassessed in Bangladesh.

The rest of the paper is organized as follows. Section 2 describes the related background and significance in the context of Bangladesh. Section 3 reflects on relevant ideas and research in our study area and develops our hypotheses. Section 4 describes our research methodology including econometric model used, variable description and data sources etc. Section 5 presents the bivariate and multivariate regression results. Section 6 concludes the paper along with avenues for further research in this area in Bangladesh.

\section{The Context of Bangladesh}

Bangladesh is an emerging economy and an interesting candidate for investigation for manifold reasons. Although, throughout the last two and half decades, the economy has performed very well questions exist regarding its sustainability (Ferdous, 2018). Ferdous (2018) reported that the economy of Bangladesh has made commendable progress with an average GDP growth rate of 5.69 per cent from 1994 until 2016. Its annual GDP growth rate has reached an all-time high of $8.13 \%$ in the fiscal year 2018 - 2019. However, under the shield of this tremendous macroeconomic growth, there is a hidden picture of the gloomy state of reality. Bangladesh is one of the countries of the world where there is high-income inequality and that is increasing. Moreover, good governance in all spheres of the economy is still an illusion in Bangladesh which is reflected in the elongated list of corporate scandals e.g. Hallmark, Bismillah Group, Oriental Bank, Modern Food Ltd etc.) (Ferdous, 2018). Bangladesh has already undergone two major stock market failures in 1996 and 2011 and still, there is severe lack of trust in the stock market among the investors as reflected in the steep volatility in the indices of the stock markets at the beginning of 2020 (Barman, 2020).

However, if further improvement and strict implementation of existing regulations regarding investor protection do not take place, the situation will exacerbate further. Good governance is a fundamental prerequisite for Bangladesh if it wants to meet its development goals (Ferdous, 2018), on one hand, and ensure investor rights and build their trust on the other.

The governance system of publicly-traded firms in Bangladesh is controlled by the Bangladesh Securities and Exchange Commission (BSEC) through the Corporate Governance Code (CGC), which has been issued on 3 June 2018 (first issued in 2006 as Corporate Governance Guidelines (CGG) on "comply or explain basis" on 20 February 2006 and was replaced in 2012 by a mandatory one (comply basis)) (Bala, 2018). This regulation has proposed a new subcommittee of the board namely the " Nomination and Remuneration Committee (NRC)" one of whose role will be to formulate the criteria for determining qualifications, positive attributes and independence of a director and recommend a policy to the Board, relating to the remuneration of the directors, top-level executive, considering the following: (i) the level and composition of remuneration is reasonable and sufficient to attract, retain and motivate suitable directors to run the company successfully; (ii) the relationship of remuneration to performance is clear and meets appropriate performance benchmarks; and (iii) remuneration to directors, top-level executive involves a balance between fixed and incentive pay reflecting short and long-term performance objectives appropriate to the working of the company and its goals (Bala, 2018). 
The regulator wants to ensure that directors` remuneration package is formulated in a way so that suitable directors perform at a level that the company achieves its short and long-term goals. Nevertheless, the existing institutional environment in Bangladesh lags behind in implementing the above-mentioned requirement. Contrary to the advanced systems of corporate governance in developed economies, typically in Bangladesh, ownership is concentrated and consequently boards are influenced/dominated by the owners having significant stakes of shares. Moreover, the firms have one-tiered boards where both executive and nonexecutive directors work collectively in one organizational layer (Rashid, De Zoysa, Lodh, \& Rudkin, 2012; Rashid, 2018) where the proportion of executive directors is higher (Adhikary \& Mitra, 2016). Given the above circumstances along with an existence of an inefficient market, less takeover regulations, and takeover processing costs, the boards have discretion and power to influence their remuneration irrespective of firms` financial performance.

The regulation requires that board pay of companies in Bangladesh be reasonably linked to company performance. This study explores and explains the current scenario regarding the link between directors' remuneration and firm performance in the stock-market listed textile firms of Bangladesh.

\section{Literature Review and Hypotheses}

The impact of corporate governance characteristics on firm performance is unsettled in academic literature (Müller, 2014). Better corporate governance in the form of stronger shareholder rights has a significant impact on the operating and financial performance of firms (Gompers, Ishii, \& Metrick, 2003). Bauwhede (2009) argued that compliance of board structure and functions can significantly affect operational efficiency and profitability of the firms. Bhagat and Bolton (2008) argued that when board stock ownership is higher, i.e. board incentive is higher, then concurrent and following operating performance of the firm is higher. They also argued that higher board incentives (higher stock ownership and higher board independence) increase disciplinary management turnover among otherwise poorly governed firms. However, some studies found negative or no association between such constructs (Bauer, $\mathrm{G}$ unster, \& Otten, 2004; Core, Guay, \& Rusticus, 2006).

Bauer et al. (2004) argued that the relationship between corporate governance and firm value vary substantially due to country effects especially differences in governance standards. There has also been broad debate on whether board independence adds any value to the firms. Some studies found a strong association of board independence and superior performance (Pearce II \& Zahra, 1991; Ezzamel \& Watson, 1993) while others found negative or no association (Bhagat \&
Black, 2002; Rashid et al., 2012). It is argued that the difference in evidence may be attributed to differences in institutional factors and managerial behaviour in the market (Fan, Wei, \& $\mathrm{Xu}, 2011$ ) or lack of methodological rigour e.g. misspecification or omission of important variables (Bathala \& Rao, 1995).

Directors` remuneration is an important issue closely connected to corporate governance (Abdullah, 2006). Abdullah argued that good corporate governance should constrain excessively high and unreasonable remuneration received by directors. Moreover, remuneration should reflect the board's contribution to firm performance. Many previous studies explored whether this takes place in different countries. For example, Gregg et al. (1993) argued that in the UK there was a very weak link between directors' remuneration and firms`economic performance indicating an ineffective system of pay determination for top company directors over the 1980s and early 1990s. But Main, Bruce, and Buck (1996) argued that the link between these two constructs appeared stronger when both long-term (share option) components were also included along with shortterm component of emoluments in total remuneration.

Müller (2014) investigated whether board remuneration characteristics influence financial performance among the listed firms in the UK and argued that corporate board compensation characteristics (non-executive directors' basic fee, fees paid in shares and additional remuneration for board committee membership) have a significant positive impact on firm financial performance. In the USA, the boards are composed of a majority of outside directors and shareholdings are dispersed leading to the true separation of ownership and management/control (Short \& Keasey, 1999). Therefore, the related studies focused mainly on the compensation of executives and outside directors (Hassan et al., 2003). Mehran (1995, p. 163) found that firm performance is highly related to managerial ownership and the portion of compensation which is equity-based and argued that the form rather than the level of compensation is what motivates managers to increase firm value.

The relationship between board remuneration and the firm`s financial performance is insignificant positive in the context of Malaysia (Hassan et al., 2003). The weak relationship is attributed to the inapplicability of normal efficient contracting predictions due to prevailing corporate governance structures. In Malaysia, there has been concentrated shareholding in the publicly traded corporations (Thillainathan, 1999) and closer control of both the board (D'Cruz, 1999) and management by substantial shareholders and dominant family owners (Hassan et al., 2003). There is a high risk of expropriation of wealth from the minority shareholders (Hassan et al., 2003) through excessive directors' remuneration packages. Abdullah (2006) also found no association between directors' remuneration and firm's profitability as measured by Return on Assets (ROA) of distressed firms in the context of Malaysia. 
In Bangladesh, several studies have explored the impact of corporate governance attributes, e.g. ownership structure (Imam \& Malik, 2007), board composition, e.g. board size, family duality, female directors ' presence, board independence (Rashid, 2018; Rahman \& Saima, 2018; Rashid et al., 2012; Meah \& Chaudhory, 2019), audit committee characteristics (Rahman, Meah, \& Chaudhory, 2019), and non-financial disclosure, e.g. intellectual capital disclosure (Rahman, Sobhan, \& Islam, 2020) on firm performance. Studies have been conducted regarding CEO compensation and banks' financial performance in Bangladesh. For example, Rahman and Muhammad (2019) found that CEO pay has significant positive impact on the performance of listed banks of Bangladesh. However, little is known regarding directors' remuneration and firm performance in Bangladesh. This paper is (according to our knowledge) is the first attempt to shed light on the directors`remuneration landscape in Bangladesh.

Unlike that of developed economies, the corporate governance system of many emerging markets including Bangladesh is afflicted with many obstacles for the board to perform the supervisory role it's supposed to play. The concentration of ownership leads to pervasive family control helping the representatives of such family owners secure positions in the board as well as the executive management (Rashid, 2018; Rashid et al., 2012; Hassan et al., 2003). This may have blurred the line of separation between dominant family owners/substantial shareholders i.e. the board that they control and the management (Hassan et al., 2003). This phenomenon may give these representatives of these family owners substantial power and discretion enabling them to expropriate the wealth of minority shareholders.

Due to this blurred line of distinction between the board and executive management when the majority of the boards of the companies are dominated by executive directors, the board's remuneration needs to be examined from the same viewpoint as executive/management remuneration has been viewed and analyzed in previous studies. The previous researchers that studied executive remuneration have adopted two different approaches: one named "optimal contracting approach" and another named "managerial power approach" to explain executive remuneration (Bebchuk \& Fried, 2003). The first approach views the remuneration as a partial solution to the problem of managerial power and discretion and states that boards design efficient compensation plans in order to provide managers with incentives that maximize shareholder value as well. The second approach usually titled "managerial power approach" views executivepay as a crucial component of the agency problem itself in addition to viewing it as a potential mechanism for addressing the problem (Bebchuk \& Fried, 2003). The later one opines that executives can significantly influence their own remuneration and eventually impose significant costs on shareholders (minority shareholders if we be specific to our context) in addition to the excessive pay they receive (Bebchuk \& Fried, 2003). Therefore, excessive managerial power and rent seeking may (in addition to excessive managerial remuneration), as Bebchuk and Fried (2003, p.72) argued, lead to dilution and distortion of managers incentives and thereby hurt firm performance.

We think that the second perspective befits our context for two reasons. First, as we have referred earlier to the fact that directors of Bangladeshi listed companies can exercise substantial power due to the underlying corporate governance and regulatory landscape in Bangladesh (Rashid et al., 2012). Second, directors' pay is not equitybased and share market lacks liquidity in Bangladesh; we could reasonably expect that the boards shall pay little attention to improve financial performance and return on shares in Bangladesh (Rashid, 2018; Bhagat \& Bolton, 2008; Hermalin \& Weisbach, 2007).

We have followed the second of the two agency problemrelated perspectives mentioned above and develop hypotheses related to the impact of our independent and control variables on our dependent variable - firm performance.

\subsection{Board of Directors' Remuneration}

Pay is an important mechanism to motivate directors to perform their duties diligently and carefully. If pay arrangement is effectively designed then it will certainly have a positive effect on the firm's financial performance. In other words, if the pay-for-performance principle is considered while designing the remuneration arrangements for directors, then directors' remuneration will indirectly and positively affect the financial performance of the firms. Although in existing evidence related to the impact of corporate governance on firm performance is mixed many studies found a positive link between board incentives and firm operating and financial performance (e.g. Bhagat \& Bolton, 2008; Hermalin \& Weisbach, 2007).

However, the extant corporate governance landscape in Bangladesh where the boards are controlled by large family owners and insider directors and there is a lack of powerful control mechanisms like an active takeover market, liquid stock market, and equity-based compensation, etc. (Rashid et al., 2012), we do not expect wide application of such optimal contracting where pay is linked to performance which will benefit minority shareholders. So, based on managerial power approach we adopted as mentioned above, we propose a negative association between the board's remuneration and firm performance in the context of Bangladeshi listed companies.

H1: There is a negative association between the board's remuneration and firm performance. 


\subsection{Percentage of Independent Directors}

According to Bangladesh corporate governance guidelines, board independence is one of the major areas for ensuring good governance. Board independence indicates the percentage of independent outside directors on the board. Independent directors are included in the board with the hope that they will make a positive contribution to the board's monitoring performance (Park \& Shin, 2004) and consequently add value to the firm (Finkelstein, Hambrick,

\& Cannella, 1996). As we have already mentioned in our short survey of previous literature above the extant evidence regarding the contribution of board independence is mixed. Merely adding independent directors overlooking underlying institutional and cultural differences in an emerging economy could not add value to firms economic performance in Bangladesh (Rashid, 2018; Rashid et al., 2012). Due to mixed evidence, we do not predict the direction of the relationship. Nevertheless, we expect a significant relationship.

H2: Board independence is strongly associated with firm performance.

\subsection{Age of the Firm}

As time goes by firms become stronger and equipped with knowledge, experience, and is better organized. Moreover, firms grow in terms of operations and turnover over time, which is an important determinant of firm performance. The higher the listing age of a firm, the higher its efficiency and maturity in dealing with the capital market (Imam \& Malik, 2007). However, older firms may perform worse than their newer counterparts when they lag in terms of innovation and use of modern technology in their business model which is one of the key determinants of competitive advantage and organizational success (Morris \& Schindehutte, 2014).

H3: There is a strong relationship between firm age and firm performance.

\subsection{Leverage of the Firm}

Leverage measures the ratio of debt and equity employed to finance the asset. The ratio increases with the increase of debt in the capital structure. Javeed \& Tabassam (2018) identified that high leverage is positively related to firms financial performance using the textile industry of Pakistan. The authors inferred that organiztions having high profitability are often encouraged to take more debt to finance asset. Imam \& Malik (2007, p. 94) argued that leverage helps reduce the cost of capital and is therefore cost-effective. Moreover, bondholders and other creditors will play a significant monitoring/corporate governance role for their own sake and improve the firm performance, in turn, to save it from bankruptcy (Imam \& Malik, 2007). On the other hand, some previous studies argued that excessive leverage could raise the finance cost of firms to an extent that financial performance may deteriorate (Rahman et al., 2020).

H4: Leverage positively influences firm performance.

\subsection{Efficiency of the Firm}

In this study, efficient firms are firms with higher asset turnover, i.e. how frequently the firms' assets generate revenues. In another sense, it indicates the productivity of the firms` assets. So, it could be argued that efficiency strengthens the financial performance of a firm.

H5: Efficiency of the firm is positively related to firm performance.

\subsection{Size of the Firm}

As firm's size increases, the firm will tend to perform better due to higher operating as well as financing efficiency, economies of scale, production efficiency as well as improved managerial skill (Imam \& Malik, 2007). Rahman et al. (2019) found positive association in the context of listed manufacturing firms in Bangladesh. Contrarily, larger firms face with higher agency costs (Raghunandan \& Rama, 2007). This may hamper financial performance of firms. For example, Rahman et al. (2020) found insignificant relationship between firm size and firm performance.

H6: The size of the firm positively affects firm performance.

\section{Methodology of the Study}

\subsection{Data Source and Econometric Model}

To see the impact of board of directors' remuneration on financial performance, the following equation needs to be estimated:

$$
F P_{i t}=\alpha+\gamma B D R_{i t}+B^{\prime} X_{i t}+\varepsilon_{i t}
$$

Here, $i(i=1,2, \ldots . .20)$ denotes the firms and $t(t=$ $2011,2012, \ldots \ldots ., 2017)$ denotes the year. $F P_{i t}$ and $B D R_{i t}$ denote the financial performance and board of directors' remuneration (natural logarithm of the total board of directors' remuneration) of the firm $i(i=1,2, \ldots . .20)$ at time $t$ ( $t=$ $2011,2012, \ldots \ldots ., 2017) . \gamma$ denotes the average changes in the financial performance for per unit change in the board of directors' remuneration, ceteris paribus. $X_{i t}$ denotes the vector of control variables used in the equation and $B$ is the 
vector of the coefficients of the control variables. Vectors$X_{i t}$ and $\mathrm{B}$ are given below:

$$
\begin{aligned}
X_{i t} & =\left[\begin{array}{l}
A G E_{i t} \\
L E V_{i t} \\
I D R_{i t} \\
E F F_{i t} \\
S I Z E_{i t}
\end{array}\right] \\
B & =\left[\begin{array}{l}
\beta_{1} \\
\beta_{2} \\
\beta_{3} \\
\beta_{4} \\
\beta_{5}
\end{array}\right]
\end{aligned}
$$

$A G E_{i t}, L E V_{i t}, I D R_{i t}, E F F_{i t}$, and $S I Z E_{i t}$ denote the age, leverage, percentage of independent directors in board of directors' panel, efficiency (measures by asset turnover), and size (measured by natural logarithm of total assets) of the firm $i(i=1,2, \ldots . ., 20)$ at time $t(t=2011,2012, \ldots \ldots$. , 2017). $\varepsilon_{i t}$ denotes the random error term.

\subsection{Definition of the Variables}

\section{Financial Performance $\left(F P_{i t}\right)$}

Financial performance has been measured by both return on assets (ROA) and returns on equity (ROE). These two measures are taken as dependent variables separately. ROA is the ratio of net income for the period and total asset. ROE is the ratio of net income and total equity of the firm. The formula of ROA and ROE are given below:

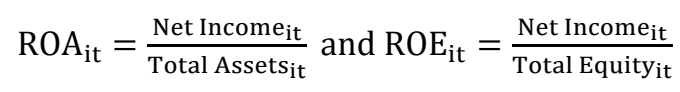

where, $i(i=1,2, \ldots . ., 20)$ and $t(t=2011,2012,2017)$.

\section{Board of Directors' Remuneration ( $\left.B D R_{i t}\right)$}

It is the incentive, which is paid to the board of directors by the firm. It is considered as the independent variable of the equation. The natural logarithm of remuneration has been used.

\section{Age of the Firm ( $\left.A G E_{i t}\right)$}

It is the natural logarithm of the number of years the firm has been established. It is used as a control variable.

\section{Leverage of the Firm ( $L E V_{i t}$ )}

It is the ratio between total debt to the total asset of the firm. It is taken as a control variable.

\section{Percentage of Independent Directors ( $\left.I D R_{i t}\right)$}

Board independence is the ratio between the number of outsides or independent director to the total number of directors in the board. It has been taken as a control variable.

\section{Efficiency of the Firm $\left(E F F_{i t}\right)$}

Efficiency has been measured by asset turnover (ATO). Asset turnover is calculated as the ratio between revenue and average total asset of the firm. It is a control variable.

\section{Size of the Firm $\left(S I Z E_{i t}\right)$}

It is measured as the natural logarithm of total asset. Firm size is used as a control variable.

\section{Results and Discussion}

\subsection{Descriptive Statistics}

Table 1 represents the results of the descriptive statistics. The mean data for the board of director's remuneration is 14.82 with the range of 12.6 to maximum 17.32. The incentives are much lower compared to Anglo-American standards. The companies should reappraise the payment structure so that pay aligns with the performance of the firm. The average ROA is 0.08 with a standard deviation of 0.07 and average ROE is 0.05 with a standard deviation of 0.08 . It indicates that the average firm performance in terms of ROA is $8 \%$ and in terms of ROE is 5\%. Mean efficiency is 0.64 which indicates that the firms did not employ total assets efficiently to generate revenue, though the maximum efficiency is 2.42 which means some firms have outperformed to utilize its asset to earn revenue. The average firm's age was 24 where the range is 11 to 56 years.

Mean leverage is 0.55 , which signifies that the firms are not highly leveraged and they are properly utilizing debt in their capital structure. The results from the table also indicate that on an average the proportion of independent directors is $24 \%$ of the board. The range starts with no independence (zero) to a maximum of $60 \%$ of total board members. The independent board proportion is very low compared to other developed countries (Rashid, 2018). The average firm's size is approximately 22 with a deviation of 0.92 . Though the firm's size is fairly moderate, the firm's performance is not increasing to that extent.

\subsection{Correlation Analysis}

It measures the extent of the relationship between the two variables. The pairwise correlation among two variables has been computed by using the following formula: 


$$
\rho_{x, y}=\frac{\sum_{i=1}^{n}\left(x_{i}-\bar{x}\right)\left(y_{i}-\bar{y}\right)}{\sqrt{\sum_{i=1}^{n}\left(x_{i}-\bar{x}\right)^{2} \cdot \sum_{i=1}^{n}\left(y_{i}-\bar{y}\right)^{2}}}
$$

Here, $\rho_{x, y}$ denotes the pairwise correlation between $x$ and $y$ where, $-1 \leq \rho_{x, y} \leq+1$

From pairwise correlation results (Table 2), it has been found that both returns on assets and return on equity are significantly negatively associated with the board of directors' remuneration. Return on assets is significantly negatively associated with the percentage of independent directors on board. Even though the return on equity is negatively associated with the percentage of independent directors, it is not statistically significant. Both returns on assets and return on equity are negatively associated with the board of directors' remuneration. Therefore, firms are not generating sufficient profit with the increased board of directors' remuneration.

Board of directors' remuneration is significantly positively associated with the size of the firm. Apparently, it can be said that board of directors is giving more emphasis on the long-term growth of the firm (increase in the total assets of the firm) however, it is not as both returns on assets and returns on equity are negatively associated with the age of the firm. Therefore, over time firms are not generating sufficient income as per increase in the size of the firm. Moreover, the competitiveness among the firms is increasing. Leverage has a positive association with both returns on assets and returns on equity. Since debt holders usually impose restrictions

Table 1: Descriptive Statistics

\begin{tabular}{|l|c|c|c|c|}
\hline & Mean & Std. Deviation & Minimum & Maximum \\
\hline BDR & 14.82 & 1.03 & 12.61 & 17.32 \\
\hline ROA & 0.08 & 0.07 & -0.16 & 0.36 \\
\hline ROE & 0.05 & 0.08 & -0.04 & 0.56 \\
\hline EFF & 0.64 & 0.44 & 0.04 & 2.42 \\
\hline AGE & 24 & 11 & 11 & 56 \\
\hline LEV & 0.55 & 0.20 & 0.10 & 1.00 \\
\hline IDR & 0.24 & 0.10 & 0.00 & 0.60 \\
\hline SIZE & 21.70 & 0.92 & 19.60 & 23.50 \\
\hline
\end{tabular}

Table 2: Pairwise Correlation among the Variables

\begin{tabular}{|c|c|c|c|c|c|c|c|c|}
\hline & ROA & ROE & BDR & AGE & LEV & IDR & EFF & SIZE \\
\hline ROA & 1.00 & & & & & & & \\
\hline ROE & $\begin{array}{l}0.72^{* * *} \\
(0.00)\end{array}$ & 1.00 & & & & & & \\
\hline BDR & $\begin{array}{l}-0.18^{* *} \\
(0.03)\end{array}$ & $\begin{array}{c}-0.24 \\
(0.00)\end{array}$ & 1.00 & & & & & \\
\hline AGE & $\begin{array}{l}-0.01 \\
(0.87)\end{array}$ & $\begin{array}{c}-0.22^{* *+*} \\
(0.00)\end{array}$ & $\begin{array}{l}-0.16 \\
(0.06)\end{array}$ & 1.00 & & & & \\
\hline LEV & $\begin{array}{c}0.05 \\
(0.53)\end{array}$ & $\begin{array}{l}0.39^{* * *} \\
(0.00)\end{array}$ & $\begin{array}{l}-0.12 \\
(0.14)\end{array}$ & $\begin{array}{c}-0.53^{n+*} \\
(0.00)\end{array}$ & 1.00 & & & \\
\hline IDR & $\begin{array}{l}-0.19^{* *} \\
(0.02)\end{array}$ & $\begin{array}{l}-0.07 \\
(0.38)\end{array}$ & $\begin{array}{l}-0.09 \\
(0.31)\end{array}$ & $\begin{array}{l}-0.18^{*} \\
(0.03)\end{array}$ & $\begin{array}{c}0.10 \\
(0.24)\end{array}$ & 1.00 & & \\
\hline EFF & $\begin{array}{c}0.10 \\
(0.23)\end{array}$ & $\begin{array}{c}0.08 \\
(0.32)\end{array}$ & $\begin{array}{l}-0.04 \\
(0.61)\end{array}$ & $\begin{array}{c}0.06 \\
(0.46)\end{array}$ & $\begin{array}{c}-0.24^{*+*} \\
(0.00)\end{array}$ & $\begin{array}{l}-0.03 \\
(0.70)\end{array}$ & 1.00 & \\
\hline SIZE & $\begin{array}{l}-0.24^{* * *} \\
(0.00)\end{array}$ & $\begin{array}{l}-0.01 \\
(0.91)\end{array}$ & $\begin{array}{l}0.46^{* * *} \\
(0.00)\end{array}$ & $\begin{array}{l}-0.47^{*+*} \\
(0.00)\end{array}$ & $\begin{array}{l}0.44^{* * *} \\
(0.00)\end{array}$ & $\begin{array}{c}0.08 \\
(0.33)\end{array}$ & $\begin{array}{l}-0.33 \\
(0.00)\end{array}$ & 1.00 \\
\hline
\end{tabular}

Note: "*'Significant at $1 \%$ level, "Significant at $5 \%$ level, and "Significant at $10 \%$ level. 
(negative covenants) on the firms' performance, firms are generating adequate income to meet the debt holders' requirements. Leverage of the firm is positively associated with the size of the firm. Therefore, leverage is being used to increase the size of the firm or simply a significant part of the firms' leverage is being used to finance capital expenditures.

\subsection{Estimation of the Model}

The second step system GMM has been used to estimate the model (Blundell \& Bond, 1998). It has augmented difference GMM estimation through the introduction of an additional assumption, which generates an additional set of moment conditions to leverage. It requires that

Table 3: VIF Results

\begin{tabular}{|c|c|c|}
\hline \multicolumn{3}{|c|}{$V I F=\frac{1}{1-R^{2}}, R^{2}=$ The goodness of fit indicator in each auxiliary regression } \\
\hline Independent Variables & Dependent Variables: ROA & Dependent Variable: $R O E$ \\
\hline SIZE & 2.13 & 2.13 \\
\hline LEV & 1.86 & 1.86 \\
\hline AGE & 1.66 & 1.66 \\
\hline BDR & 1.61 & 1.61 \\
\hline EFF & 1.18 & 1.18 \\
\hline IDR & 1.06 & 1.06 \\
\hline Mean VIF & 1.58 & 1.58 \\
\hline
\end{tabular}

Table 4: GMM Estimation Results of Equation-1

\begin{tabular}{|c|c|c|}
\hline Independent Variables' Coefficients & Dependent Variable: ROA & Dependent Variable: ROE \\
\hline Constant & $\begin{array}{l}0.8353^{* * *} \\
(0.0000)\end{array}$ & $\begin{array}{c}0.2188 \\
(0.3160) \\
\end{array}$ \\
\hline $\mathrm{ROA}(-1)$ & $\begin{array}{l}0.0906^{* * *} \\
(0.0080)\end{array}$ & - \\
\hline $\mathrm{ROE}(-1)$ & - & $\begin{array}{l}0.5749 * * \\
(0.0000)\end{array}$ \\
\hline BDR & $\begin{array}{l}-0.0161^{\text {t*t }} \\
(0.0030)\end{array}$ & $\begin{array}{l}-0.0306^{\text {t** }} \\
(0.0000)\end{array}$ \\
\hline AGE & $\begin{array}{l}-0.0020^{*} \\
(0.0830)\end{array}$ & $\begin{array}{c}-0.0009 \\
(0.6080)\end{array}$ \\
\hline LEV & $\begin{array}{l}-0.0915^{*+*} \\
(0.0040)\end{array}$ & $\begin{array}{l}0.1317^{* * *} \\
(0.0060)\end{array}$ \\
\hline IDR & $\begin{array}{c}0.0814 \\
(0.4100) \\
\end{array}$ & $\begin{array}{c}-0.0454 \\
(0.6120) \\
\end{array}$ \\
\hline EFF & $\begin{array}{c}0.0877^{* *} \\
(0.0240)\end{array}$ & $\begin{array}{c}0.0899^{* *} \\
(0.0330)\end{array}$ \\
\hline SIZE & $\begin{array}{l}-0.0235^{* * *} \\
(0.0000)\end{array}$ & $\begin{array}{c}0.0073 \\
(0.1910)\end{array}$ \\
\hline $\mathrm{N}$ & 120 & 120 \\
\hline AR (2) Statistic & $\begin{array}{c}0.6755 \\
(0.4993)\end{array}$ & $\begin{array}{c}-0.2711 \\
(0.7863)\end{array}$ \\
\hline Sarjan J-Statistic & $\begin{array}{c}7.1680 \\
(0.5186)\end{array}$ & $\begin{array}{c}8.6889 \\
(0.3692)\end{array}$ \\
\hline
\end{tabular}

Note: ${ }^{* * *}$ Significant at $1 \%$ level, ${ }^{* *}$ Significant at $5 \%$ level, and ${ }^{*}$ Significant at $10 \%$ level 
lagged changes in the dependent variable are the valid instruments for the level of lagged dependent variable in the level equation. To sum up, system GMM requires more assumptions than difference GMM, and if the assumptions hold, it will achieve greater efficiency. Before estimation of the model, it is inevitable to check the multicollinearity among the variables. To check multicollinearity among the variables, the variance inflation factor (VIF) has been used. The results of VIF and estimated results of the model have been given below in Table- 3 and Table-4 respectively.

If the variance inflation factor is greater than or equal to 10 , then multicollinearity will be a serious problem. From Table-3, it can be concluded that there is no severe multicollinearity problem, since all variance inflation factors are less than $10(<10)$.

Table 4 presents the GMM estimation results of equation -1 along with number of observations, AR (2) Statistic and Sargan J-Statistic. The AR (2) It shows that financial performance (as measured by ROA and ROE) is negatively associated with board remuneration. Higher remuneration cannot sufficiently incentivize the board to strengthen the reported financial performance of the firm to an extent that exceeds the reduction in contemporaneous accounting earnings due to this higher remuneration. In short higher-paid boards do not perform well enough to significantly boost firms`subsequent financial performance. Whereas previous studies noted that directors' incentives (stock ownership of board members, equity-based compensation) have a positive impact on firm performance (Bhagat \& Bolton, 2008), we have found a negative relation between board remuneration and firm performance in Bangladesh. We attribute this phenomenon to the lack of equity-based compensation and the absence of a liquid capital market in Bangladesh (Rashid et al., 2012).

While board remuneration in developed countries comprises of both short-term emoluments and long-term equity-based components (Main et al., 1996), the boards in Bangladesh are not paid in shares or share options. This lack, coupled with lack of other control mechanisms like an inefficient market for corporate control characterized by inefficient stock market, scarce takeover regulation, higher takeover processing costs, unhealthy regulatory response etc. have failed to incentivize the board to strive for improved firm performance.

Table 4 also reports an insignificant relationship between firm performance and board independence. This indicates the poor and disappointing role the independent board members play for shareholders of firms. It is consistent with Rashid (2018, p. 44) who found that board independence does not improve firm performance in the context of Bangladesh. The reason is the limited ability these directors have to perform their tasks in emerging markets (Rashid, 2018) due to underlying institutional and cultural differences (Rashid et al., 2012). Bangladesh lacks takeover regulations, has an inefficient market, and there are transaction costs associated with takeover processes (Rashid et al., 2012).

We have also found a negative relationship between firm age and firm performance, which indicates that older firms are not probably doing well due to older business models. Leverage has been found to negatively affect the return on assets and positively affect the return on equity. Efficiency has been found to have a positive impact on firm performance consistent with our expectations. Firm size negatively affects return on assets and has negligible impact on return on equity.

\section{Conclusions}

We have investigated the impact of board pay on firm performance among a sample of listed companies in Bangladesh. The study encompasses 20 listed textile companies of Dhaka Stock Exchange (DSE) during the period from 2011 to 2017. Our findings, estimated using GMM method, suggest that higher pay to the board does not guarantee higher firm performance and in turn results in shareholders getting nothing in return from this. Our result indirectly indicates that currently directors` remuneration in Bangladesh is not aligned with the firm performance, which has been emphasized in the CGC of 2018 (Bala, 2018). Moreover, we have found that independent directors on the boards have an insignificant impact on firm performance.

We recommend that the pay mechanism that governs directors` remuneration must be reappraised and reformed along with reforming the underlying institutional environment surrounding corporate governance that previous studies suggested. For example, properly articulated equity-based compensation plans while keeping ownership concentration at a certain level especially by putting a ceiling to directors shareholding (Meah \& Chaudhory, 2019) may act as a partial solution to the incentive problem facing the boards of textile firms. Our findings have implications for economic policy makers and corporate regulators. Our study has certain limitations in scope and methodology, for example, relatively small sample size and ignoring possible simultaneity of association between our main variables. Further research can explore whether our results are consistent and robust in other industry sectors using our model and also simultaneous equation models.

\section{References}

Abdullah, S. N. (2006). Directors' remuneration, firm's performance and corporate governance in Malaysia among distressed companies. Corporate Governance, 6(2), 162-174. 
Adhikary, B., \& Mitra, R. (2016). Determinants of Audit Committee Independence in the Financial Sector of Bangladesh. Applied Finance and Accounting, 2(2), 46-56.

Bala, S. K. (2018, June). Corporate Governance Code 2018 in Bangladesh: Reforms and Revisions. Monthly Review, 24-35.

Barman, B. (2020, January 2020). Stocks rebound strongly on govt move: DSEX sees biggest single-week gain in seven-year. The Financial Express, January 21. Dhaka, Bangladesh.

Bathala, C. T., \& Rao, R. P. (1995). The determinants of board composition: An agency theory perspective. Managerial and Decision Economics, 16(1), 59-69.

Bauer, R., Güunster, N., \& Otten, R. (2004). Empirical Evidence on Corporate Governance in Europe: The effect on stock returns, firm value and performance. Journal of Asset Management, 5(2), 91-104.

Bauwhede , H. V. (2009). On the relation between corporate governance compliance and operating performance. Accounting and Business Research, 39(5), 497-513.

Bebchuk, L. A., \& Fried, J. M. (2003). Executive Compensation as an Agency Problem. Journal of Economic Perspectives, 17(3), 71-92.

Bhagat, S., \& Black, B. (2002). The Non-Correlation between Board Independence and Long-Term Firm Performance. Journal of Corporate Law, 27(2), 231-274.

Bhagat, S., \& Bolton, B. (2008). Corporate governance and firm performance. Journal of Corporate Finance, 14(3), 257-273.

Blundell, R., \& Bond, S. (1998). Initial conditions and moment restrictions in dynamic panel data models. Journal of Econometrics, 87(1), 115-143.

Brennan , N. (2006). Boards of Directors and Firm Performance: Is there an Expectations Gap? Corporate Governance: An International Review, 14(6), 577-593.

Core, J. E., Guay, W. R., \& Rusticus, T. O. (2006). Does Weak Governance Cause Weak Stock Returns? An Examination of Firm Operating. The Journal of Finance, 61(2), 655-687.

D’Cruz, N. (1999, July 3). Corporate Governance Under Threat, Says a Business Leader. Bernama.

Ezzamel, M., \& Watson, R. (1993). Organizational Form, Ownership Structure and Corporate Performance: A Contextual Empirical Analysis of UK Companies. British Journal of Management, 4(3), 161-176.

Fan, J. P., Wei, J. K., \& Xu, X. (2011). Corporate finance and governance in emerging markets: A selective review and an agenda for future research. Journal of Corporate Finance, $17(2), 207-214$.

Ferdous, C. S. (2018). Corporate Governance in Bangladesh: Evidence of Compliance. International Business Research, 11(3), 88-109.

Finkelstein, S., Hambrick, D. C., \& Cannella, A. A. (1996). Strategic leadership. St. Paul, MN: West Educational Publishing.
Gompers, P., Ishii, J., \& Metrick, A. (2003). Corporate Governance and Equity Prices. The Quarterly Journal of Economics, 118(1), 107-156.

Gregg, P., Machin, S., \& Szymanski, S. (1993). The Disappearing Relationship Between Directors' Pay and Corporate Performance. British Journal of Industrid Relations, 31(1), 1-9.

Hassan, S., Christopher, T., \& Evans, R. (2003). Directors' Remuneration and Firm Performance: Malaysian Evidence. Malaysian Accounting Review, 2(1), 57-67.

Hermalin, B., \& Weisbach, M. (2007). Transparency and corporate governance. University of California and University of Illinois working paper.

Imam, M. O., \& Malik, M. (2007). Firm Performance and Corporate Governance Through Ownership Structure: Evidence from Bangladesh Stock Market. International Review of Business Research Papers, 3(4), 88-110.

Javeed, L., \& Tabassam, R. (2018). Financial Leverage and Financial Performance: Empirical Evidence From Listed Textile Industry of Pakistan. International Journal of Accounting and Financial Reporting, 8(4).

Main, B. G., Bruce,A., \& Buck, T. (1996). Total Board Remuneration and Company Performance. The Economic Journal, 106(439), 1627-1644.

Meah, R. M., \& Chaudhory, N. U. (2019). Corporate Governance and Firm's Profitability: An Emerging Economy-based Investigation. Indian Journal of Corporate Governance, 12(1), 71-93.

Mehran, H. (1995). Executive compensation structure, ownership, and firm performance. Journal of Financial Economics, 38, 163-184.

Morris, M. H., \& Schindehutte, M. (2014). Chapter 12: Teaching entrepreneurship students how to design a business model. In M. M. H., Annals of Entrepreneurship Education and Pedagogy - 2014 (pp. 242-255). Edward Elgar Publishing.

Müller, V.-O. (2014). Do corporate board compensation characteristics influence the financial performance of listed companies? Procedia - Social and Behavioral Sciences, 109, 983-988.

Park, Y. W., \& Shin, H.-H. (2004). Board composition and earnings management in Canada. Journal of Corporate Finance, 10(3), 431-457.

Pearce II, J. A., \& Zahra, S. A. (1991). The relative power of ceos and boards of directors: Associations with corporate performance. Strategic Management, 12(2), 135-153.

Raghunandan , K., \& Rama, D. (2007). Determinants of Audit Committee Diligence. Accounting Horizons, 21(3), 265-279.

Rahman, M. M., \& Muhammad, T. (2019). The Impact of CEO's Compensation on Firm's Performance: Empirical Evidence from Listed Banks of Bangladesh. Journal of Banking and Financial Services, 11(1), 149-170. 
Rahman, M. M., \& Saima, F. N. (2018). Efficiency of Board Composition on Firm Performance: Empirical Evidence from listed Manufacturing Firms of Bangladesh. Journal of Asian Finance, Economics and Business, 5(2), 53-61. https://doi. org/10.13106/jafeb.2018.vol5.no2.53

Rahman, M. M., Meah, M. R., \& Chaudhory, N. U. (2019). The Impact of Audit Characteristics on Firm Performance: An Empirical Study from an Emerging Economy. Journal of Asian Finance, Economics and Business, 6(1), 59-69. http://doi. org/10.13106/jafeb.2019.vol6.no1.59

Rahman, M. M., Sobhan, R., \& Islam, M. S. (2020). The Impact of Intellectual Capital Disclosure on Firm Performance: Empirical Evidence from Pharmaceutical and Chemical Industry of Bangladesh. Journal of Asian Finance, Economics and Business, 7(2), 119-129. https://doi.org/10.13106/jafeb.2020.vol7.no2.119
Rashid , A., De Zoysa, A., Lodh, S., \& Rudkin, K. (2012). Board composition and firm performance: Evidence from Bangladesh - a sceptical view. Australasian Accounting Business and Finance Journal, 6(3), 121-131.

Rashid, A. (2018). Board independence and firm performance: Evidence from Bangladesh. Future Business Journal, 4, 34-49.

Rose, C. (2005). The Composition of Semi-Two-Tier Corporate Boards and Firm Performance. Corporate Governance: An International Review, 13(5), 691-701.

Short, H., \& Keasey, K. (1999). Managerial Ownership and the Performance of Firms: Evidence from the UK. Journal of Corporate Finance, 5(1), 79-101.

Thillainathan. (1999). Role of Shareholders, Directors and Managers in Corporate Governance. The World Bank. 